\title{
The investigation of tumoral angiogenesis with HIF- 1 alpha and microvessel density in women with endometrium cancer
}

\section{Endometrium kanserli olgularda tümör anjiogenezinin HIF-1 alfa ve mikrodamar dansitesi ile değerlendirilmesi}

\author{
Aysun Aybatlı' ${ }^{1}$ Cenk Sayın ${ }^{1}$, Petek Balkanlı Kaplan ${ }^{1}$, Füsun Varol ${ }^{1}$, Şemsi Altaner ${ }^{2}$, Necdet Süt ${ }^{3}$ \\ 'Department of Obstetrics and Gynecology, Faculty of Medicine, Trakya University, Edirne, Turkey \\ ${ }^{2}$ Department of Pathology, Faculty of Medicine, Trakya University, Edirne, Turkey \\ ${ }^{3}$ Department of Biostatistics, Faculty of Medicine, Trakya University, Edirne, Turkey
}

\section{Abstract}

Objective: Hypoxia inducible factor 1 alpha (HIF-1 $\alpha$ ) is a nuclear
protein upregulated in response to reduced cellular oxygen concen-
tration which therefore acts as a marker for hypoxia. The aim of this
study was to determine tumoral angiogenesis with immunohisto-
chemical markers in endometrium cancer and its relation with stage,
grade, survival rates and other prognostic factors. Material and Methods: Using the database in our Gynecologic Oncology clinic, we selected 94 patients who were diagnosed with endometrial cancer and underwent primary surgery at our institution between 2001 and 2010. Tissue microarrays believed to demonstrate the optimum part of the tumor were reprepared from the paraffin blocks. Angiogenesis and microvessel density (MVD) were investigated with the aid of HIF- $1 \alpha$ and CD34 antibodies.

Results: High expression of HIF-1 $\alpha$ was significantly more frequent in advanced grade endometrial cancers $(\mathrm{p}=0.044)$. HIF- $1 \alpha$ expression was highly correlated with CD34 expression in the tumor cells $(\mathrm{p}<0.001)$. However lack of relation among stage, overall survival rates and histological types were analyzed with HIF-1 $\alpha$. When we compared HIF- $1 \alpha$ positive and negative cases with cervical, adnexial, lymphovascular and myometrial invasion, there was no difference between these groups. MVD was evaluated with CD34 and it was remarkable and significantly different on advanced grade tumors $(\mathrm{r}=0.268 ; \mathrm{p}=0.009)$. A similar significant difference was observed between the high expression of CD34 and type II endometrial cancer histology $(\mathrm{p}<0.001)$. However, there was no relationship between the MVD and stage or survival rates.

Conclusion: High expression of HIF- $1 \alpha$ is associated with tumoral angiogenesis in endometrial adenocarcinomas. Further studies targeting HIF-1 $\alpha$ for disrupting mechanisms essential for tumor growth in endometrium cancer will be significant investigations in the future.

(J Turkish-German Gynecol Assoc 2012; 13: 37-44)

Key words: Endometrium cancer, HIF-1 $\alpha$, hypoxia, angiogenesis

Received: 21 April, 2011

Accepted: 3 December, 2011

\section{Özet}

Amaç: Hipoksi ile indüklenen faktör-1 $\alpha$ (HIF-1 $\alpha)$ bir nükleer proteindir ve azalan hücre içi oksijen konsantrasyonuna cevap olarak regüle edilir. Bu nedenle bir hipoksi belirteci gibi görev yapar. Bu çalışmanın amacı endometrium kanserli olgularda tümör anjiogenezini immunohistokimyasal belirteçler ile incelemek ve evre, derece ve sağkalım gibi prognostik faktörlerle olan bağlantısını aydınlatmaya çalışmaktır.

Gereç ve Yöntemler: 2001 ile 2010 tarihleri arasında Jinekolojik Onkoloji Bölümü'nde endometrium kanseri nedeniyle tanı alan ve ameliyat edilen 94 olgu çalışmaya dahil edildi. Olguların tümörü en iyi gösterdiğine inanılan kesitlerinin parafin blokları tekrar oluşturulup, HIF-1 $\alpha$ ve CD34 antikorlanı kullanılarak anjiogenez ve mikrodamar dansitesi (MDD) değerlendirildi.

Bulgular: HIF-1 $\alpha$ pozitifliği ile yüksek grada sahip endometrium kanserli olgular arasındaki fark istatistiksel olarak anlamlı idi $(p=0.044)$. Kullanılan immunohistokimyasal belirleyicilerin boyanma sonuçları birbiri ile karşılaştıııldığında HIF-1 $\alpha$ pozitifliği izlenen olgularda CD34 ekspresyonunun daha fazla olduğu görüldü $(p<0.001)$. HIF-1 $\alpha$ ile evre, toplam sağkalım, histolojik tip arasında anlamlı ilişki saptanmadı. HIF$1 \alpha$ pozitif ve negatif olguların servikal, adneksiyal, lenfovasküler ve myometrial invazyon özellikleri kıyaslandığında iki grup arasında fark gözlenmedi. CD34 ile değerlendirilen mikrodamar dansitesinin derece (grad) ve histolojik tip ile yaplan analizinde ise ileri grad tümörlerde ve tip II histolojik tip endometrium kanserlerinde mikrodamar dansitesi yüksek olarak belirlendi $(r=0.268 ; p=0.009, p<0.001)$. Mikrodamar dansitesi ile evre ve sağkalım üzerinde ise anlamlı bir ilişki görülmedi.

Sonuç: HIF-1 $\alpha$ ekspresyonu ile endometrium adenokanserleri tümör anjiogenezi arasında bir ilişki mevcuttur. Endometrium kanserlerinde tümör gelişimi için gerekli yolakları engelleyebilecek HIF-1 $\alpha$ odaklı çalışmalar ilerleyen zamanların ilgi çekici araştırma konularından olacaktır. (J Turkish-German Gynecol Assoc 2012; 13: 37-44)

Anahtar kelimeler: Endometrium kanseri, HIF-1 $\alpha$, hipoksi, anjiogenez Geliş Tarihi: 21 Nisan 2011

Kabul Tarihi: 03 Aralık 2011 


\section{Introduction}

Endometrial cancer is the most commonly identified invasive neoplasm of the female genital tract and the fifth most common cancer in the female population. New cases diagnosed each year in the world number approximately 150,000 (1). According to the clinicopathological features and genetic basis, endometrium cancers have been classified into two major types: type I and type II. Endometrioid and mucinous tumors also referred to as type I are well differentiated neoplasms and usually related with estrogen stimulation. Serous and clear cell carcinomas known as type II tumors, on the other hand, fail to produce regular patterns, demonstrating nuclear atypia, high mitotic activity and poor prognosis (2).

Angiogenesis is essential for tumor growth, invasion, and metastasis. If neovascularization is absent, tumors cannot grow because oxygen lack in the centre of the tumor results in apoptosis and necrosis. Therefore, cancer cells have to adapt themselves to hypoxia by several mechanisms (3).

Hypoxia inducible factor-1 (HIF-1), that is a major regulator of cell adaptation to hypoxic stress, plays a critical role in angiogenesis. HIF-1 is composed of the two subunits HIF-1 $\alpha$ and HIF-1 $\beta$. A common subunit, HIF-1 $\beta$, is constitutively expressed in both normoxia and hypoxia. The oxygen-regulated subunit is HIF-1 $\alpha$ and it determines HIF-1 activity. Under nonhypoxic conditions, HIF-1 $\alpha$ is subject to ubiquitination and proteasomal degradation. However in hypoxia, its activity is stabilized (4). HIF-1 $\alpha$ controls the expression of more than 40 target genes whose protein products play crucial roles in cellular pathways including angiogenesis, tumoral growth, erythropoiesis and biological events associated with aggressive tumor behavior (5). HIF-1 $\alpha$ expression is increased in many cancers including bladder, ovary, lung, pancreas and gastrointestinal stromal tumors (6). HIF-1 $\alpha$ upregulation has been demonstrated to be absent in the inactive endometrium but present in hyperplasia and endometrioid type adenocarcinoma, with increasing expression (7). However, the role of HIF-1 $\alpha$ expression in other types of endometrial carcinoma and its association with grade, stage, invasion depth, survival and prognosis have not been well documented in the literature.

The aim of this study was to evaluate the tumoral angiogenesis and the expression of HIF- $1 \alpha$ protein in relation to microvessel density (MVD) and to investigate relationships with the other clinicopathologic features in type I and type II endometrial adenocarcinomas.

\section{Materials and Methods}

The materials for this study were retrieved from the database of the Department of Obstetrics and Gynecology and Division of Pathology, Pathology, Trakya University, Faculty of Medicine, between 2001 and 2010. We identified 100 formalin-fixed, paraffin-embedded tumor samples from women with endometrial adenocarcinoma who underwent surgery at our institution. After obtaining approval from the Ethical committee of our institution, we performed a retrospective chart review of the patients' demographic, pathological and clinical data.

The histological type of endometrial cancer was determined using the World Health Organization (WHO) criteria (8). The tumors were classified as type I (endometrioid and mucinous) and type II (serous and clear cell). Mucinous tumors were excluded in the study and all patients with type II histology (clear and serous cell), diagnosed and operated in our center throughout the study period were included. Additionally, all advanced-staged and high grade type I endometrial adenocarcinomas were also included in this study. For obtaining homogenous distribution, we carefully selected cases in which equalisation of the grade I, II and III in each group was attempted. Surgical staging was determined using the revised criteria recommended by the International Federation of Gynecology and Obstetrics, 2009 (FIGO) (9). All patients underwent total abdominal hysterectomy with pelvic and paraaortic lymphadenectomy with or without salphingoophorrectomy. If the patient had Type II tumor, an omentectomy and appendectomy were also performed. Microscopic grading was based on the FIGO grading system. All type II cancers were accepted as grade III tumors. The specimens were evaluated for the stage and grade of the tumor, adnexial and lymphovascular involvement, cervical and myometrial invasion.

After the initial evaluation, of 100 cases, 6 patients were excluded from the study due to the unavaliability of their paraffin block for immunohistochemical staining. Therefore, ninety-four hysterectomy specimens from patients operated on for endometrium cancer were analyzed and the paraffin-embedded blocks believed to demonstrate the optimum part of the tumor were reprepared. Angiogenesis and microvessel density were investigated with the aid of HIF- $1 \alpha$ and CD34 antibodies.

Expression of HIF-1 $\alpha$ and CD 34 was determined immunohistochemically, using the avidin-biotin-peroxidase technique. $4-5 \mu$ thick slides were deparaffinized in xylol. Slides were heated in $0.01 \mathrm{M}$ citrate buffer for $20 \mathrm{~min}$ in a microwave oven. For HIF-1 $\alpha$, sections were antigen retrieved by using an EDTA buffer. After cooling for $20 \mathrm{~min}$ and washing in phosphate-buffered saline solution (PBS), endogenous peroxidase was blocked with $3 \%$ $\mathrm{H} 2 \mathrm{O} 2$ for $10 \mathrm{~min}$, followed by cooling for $20 \mathrm{~min}$ and washing in PBS. The slides were then incubated for overnight at $4^{\circ} \mathrm{C}$ temperature with primary antibodies against HIF-1 $\alpha$ (1:300, Clone H1alpha67) and CD 34 (1:100, Clone QBEND/10) (Table 1). Positive controls were used as follows: Cervical squamous cell cancer - HIF-1 $\alpha$ and endometrium- CD34.

Table 1. Immunohistochemical methods

\begin{tabular}{|l|c|c|}
\hline Antibody & Code & Incubation period \\
\hline HIF-1 $\alpha$ Ab-4 / MCL- mouse & Thermo-Scientific night \\
(Clone H1alpha67) & $/$ MS-1164-P1 & 30 minute \\
\hline CD34 / MCL- mouse & Seytek \\
(Clone QBEND-10) & / A00070 \\
\hline
\end{tabular}




\section{Assessment of immunohistochemistry}

Expression of HIF-1 $\alpha$ is seen in both nucleus and cytoplasm (10). However, only nuclear staining was assessed in this study. The extent and intensity of the nuclear staining were measured separately. For HIF-1 $\alpha$ assessment, staining intensity was scored as 0 (negative), 1 (weak), 2 (medium), and 3 (strong). Extent of staining was scored as 0 (0\%), 1 (1-25\%), 2 (26-50\%), 3 (51$75 \%)$, and $4(76-100 \%)$ according to the percentages of the positive staining areas in relation to the whole carcinoma area. The sum of the intensity and extent score was used as the final staining score (0-7) for HIF-1 $\alpha$. Tumors having a final staining score of $>2$ were considered to be positive (10).

For MVD assessment, microvessels were evaluated immunohistochemically by CD34. A modification of the technique described by Weidner et al. (11) was used in determining MVD. Sections were first scanned at low power $(\times 40$ and $\times 100)$. Then the highest vascularization areas, called 'hot spots', were chosen at a magnification of $\times 100$ and microvessel counting was

Table 2. Stages of cases with type I\&II histology

\begin{tabular}{|l|c|c|}
\hline Stage & $\begin{array}{c}\text { Type I } \\
\text { Cases (\%) }\end{array}$ & $\begin{array}{c}\text { Type II } \\
\text { Cases (\%) }\end{array}$ \\
\hline I & $50(53.2 \%)$ & $3(3.2 \%)$ \\
\hline II & $10(10.6 \%)$ & $1(1.1 \%)$ \\
\hline III & $14(14.9 \%)$ & $13(13.8 \%)$ \\
\hline IV & $2(2.1 \%)$ & $1(1.1 \%)$ \\
\hline
\end{tabular}

Table 3. Clinicopathological features of cases with endometrial cancer

\begin{tabular}{|c|c|c|}
\hline $\begin{array}{l}\text { Clinico-histopathological } \\
\text { characteristics }\end{array}$ & & Cases (\%) \\
\hline \multirow[t]{2}{*}{ Type } & I & $76(80.9 \%)$ \\
\hline & II & $18(19.1 \%)$ \\
\hline \multirow[t]{8}{*}{ Stage } & IA & $45(47.9 \%)$ \\
\hline & IB & $8(8.5 \%)$ \\
\hline & II & $11(11.7 \%)$ \\
\hline & IIIA & $7(7.4 \%)$ \\
\hline & IIIB & $1(1.1 \%)$ \\
\hline & IIIC1 & $12(12.8 \%)$ \\
\hline & IIIC2 & $7(7.4 \%)$ \\
\hline & IVB & $3(3.2 \%)$ \\
\hline \multirow[t]{3}{*}{ Grade } & 1 & $36(38.3 \%)$ \\
\hline & 2 & $30(31.9 \%)$ \\
\hline & 3 & $28(29.8 \%)$ \\
\hline \multirow[t]{3}{*}{ Histological Type } & Endometrioid & $76(80.9 \%)$ \\
\hline & Clear cell & $9(9.6 \%)$ \\
\hline & Serous & $9(9.6 \%)$ \\
\hline \multirow[t]{2}{*}{ Recurrence } & $(-)$ & $85(90.4 \%)$ \\
\hline & $(+)$ & $9(5.6 \%)$ \\
\hline
\end{tabular}

performed at a magnification of $\times 200$ in 5 different 'hot spot' areas. The final microvessel score was defined as the average of the vessel counts from five high vascularization areas.

\section{Statistical analysis}

Statistical analyses and graphs were performed by using Statistical Software Package for the Social Sciences, (SPSS). Correlations between HIF expression and different clinicopathological parameters was performed by the Student $t$ test, Fisher's exact test or the Mann-Whitney U test as appropriate. Correlation between two continuous and ordinal variables were determined by the Pearson correlation and Spearman's rank test, respectively. Survival times were estimated in months from the date of diagnosis to the date of death or last followup and survival curves were plotted using the Kaplan-Meier method. Statistical significance was defined as a probability value less than 0.05 .

\section{Results}

To study the tumoral angiogenesis with HIF-1 $\alpha$ and CD34 in type I and II endometrial carcinoma, we analysed 94 tumor tissue sections for HIF- $1 \alpha$ and CD34 expression. 76 type I and 18 type II endometrial adenocarcinomas were retrieved from these slides. The mean age at the time of diagnosis was $59.96 \pm 9$ years (range: 31-80). Using the revised FIGO staging system (9): 53 cases of Stage I (56.4\%), 11 cases of Stage II (11.7\%), 27 cases of Stage III (28.7\%), and 3 cases of Stage IV (3.2\%) were determined. Table 2 also demonstrates stage according to the histological type. Based on the FIGO grading system, 36 cases were classified as Grade I (38.3\%), 30 cases were Grade II (31.9\%) and 28 cases were Grade III (29.8\%). The clinicopathological data of the patients are listed in Table 3 and 4 .

Median follow-up was 31 \pm 10.6 months (range, 1-95 months). During follow-up, 9 patients developed distant recurrences (9.6\%). Recurrence sites were the intestine and colon in 3 cases, lumbar vertebra in 5 cases and multiple localization in the body including pelvis in 1 case. Thus, the total number of women with pelvic recurrences was 4 . The median follow-up in

Table 4. Histopathological features

\begin{tabular}{|l|c|c|}
\hline \multicolumn{2}{|l|}{ Myometrial invasion } & $\begin{array}{c}\text { Number of } \\
\text { cases (\%) }\end{array}$ \\
\hline \multirow{2}{*}{ Myometrial invasion } & No & $10(10.6 \%)$ \\
\cline { 2 - 3 } & Yes & $84(89.4 \%)$ \\
\hline \multirow{2}{*}{ Cervical invasion } & No & $63(67 \%)$ \\
\cline { 2 - 3 } & Yes & $31(33 \%)$ \\
\hline \multirow{2}{*}{ Lymphovascular invasion } & No & $60(63.8 \%)$ \\
\cline { 2 - 3 } & Yes & $34(36.2 \%)$ \\
\hline \multirow{2}{*}{ Lymph node metastasis } & No & $67(71.2 \%)$ \\
\cline { 2 - 3 } & Yes & $27(28.7 \%)$ \\
\hline \multirow{2}{*}{ Adnexal involvement } & No & $74(78.7 \%)$ \\
\cline { 2 - 3 } & Yes & $20(21.3 \%)$ \\
\hline
\end{tabular}


patients with recurrence was 44.8 months. Of 9 recurrent cases, clear cell histology was defined in 4 cases, serous cell type in 3 and endometrioid type in 2 cases. Also, to compare according to the stage, 7 recurrent cases were in stage III, 1 case in stage II and 1 case in stage I. During follow-up of these 9 cases, 4 patients died.

In the study, the impact of cervical, myometrial, adnexal and lymphovascular invasion on overall survival (OS) was also investigated. Only the positivity of the adnexal involvement and lymphovascular invasion were observed to be significant statistically $(\mathrm{p}<0.001, \mathrm{p}<0.001)$.

The overall survival, disease free survival (DFS), progression free survival (PFS) and survival rates of all cases were analyzed (Table 5). In the comparison of survival parameters between type I and type II patients, statistical significance was found in all of these four survival times (Figure 1). Looking at the relationship between the survival rates and the stage, we found that survival rates declined in advanced-staged cancers.

\section{Immunohistochemical findings}

Ninety-four hysterectomy specimens from patients operated on for endometrium cancer were evaluated by immunohistochemical analysis. The positive nuclear reaction with HIF- $1 \alpha$ was observed in 28 (29.7\%) patients. As mentioned earlier, only the nuclear reaction was accepted as positive for HIF-1 $\alpha$ expression (Figure 2, 3). According to the histological type, no significant difference in expression of HIF-1 $\alpha$ between type I and type II ndometrial adenocarcinoma (24 of type I vs 4 of type II; $\mathrm{p}=0.318$ ) was observed (Table 6 ).

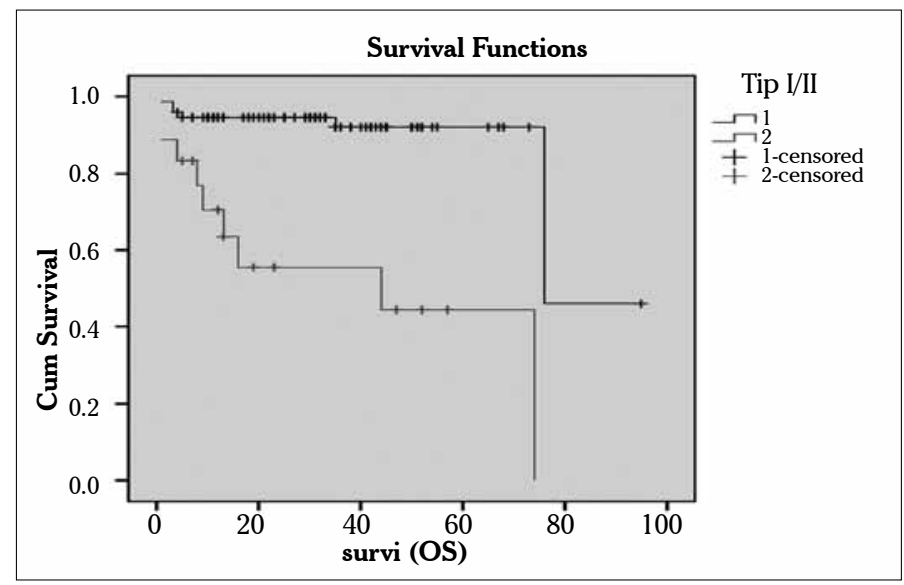

Figure 1. Overall survival of patients with type I and II cancer Cum Survival: Overall survival, Survi (OS): Survival in months 1: Type I cancers 2: Type II cancers, Kaplan-Meier method)
High expression of HIF-1 $\alpha$ was seen in $19.4 \%$ of grade I, $46.7 \%$ of grade II and $25 \%$ of grade III tumors of all the study population $(p=0.044)$. We also found that there was still a significant difference between grade and HIF-1 $\alpha$ expression by exluding type II tumors from the analysis $(p=0.008)$. Since all type II tumors were accepted as grade III, we investigated the relationship between grade and HIF-1 $\alpha$ expression in type I patients by generating a homogenous group (Table 7). According to the stage, HIF-1 $\alpha$ positive and negative cases were listed in Table 8. No significance was found between the stage and HIF-1 $\alpha$ expression.

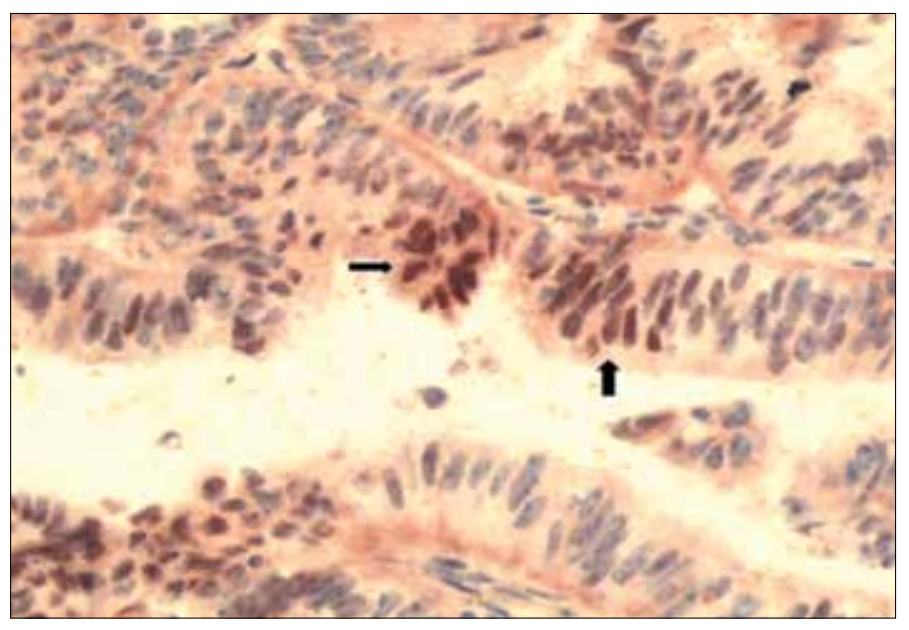

Figure 2. HIF-1 $\alpha$ positivity in endometrioid type adenocarcinoma (HIF-1 $\alpha$, X200)

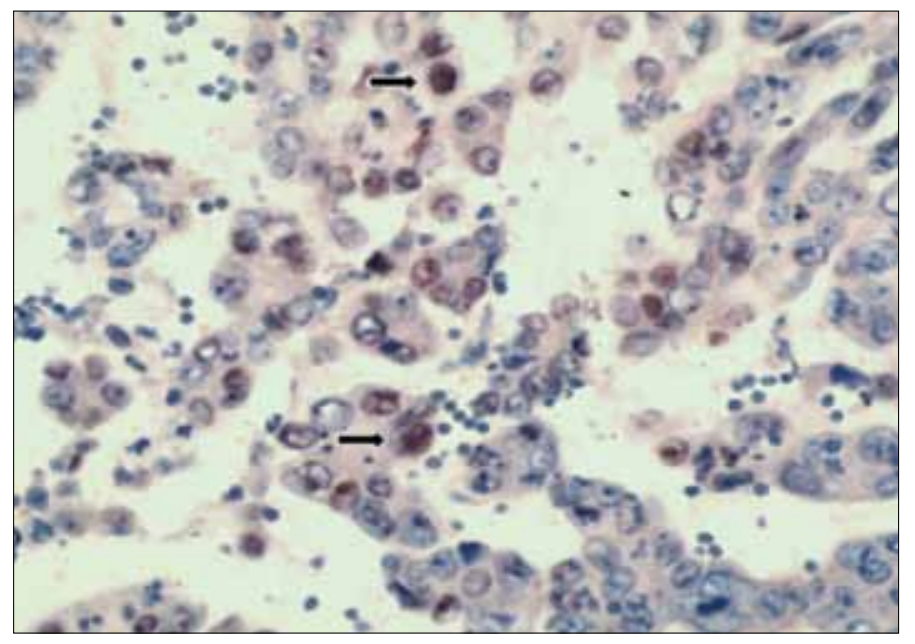

Figure 3. HIF-1 $\alpha$ positivity in serous type adenocarcinoma (HIF$1 \alpha, \mathrm{X} 200$ )

Table 5. Survival times and rates of patients

\begin{tabular}{|c|c|c|c|c|}
\hline & $\begin{array}{l}\text { All cases } \\
(n=94)\end{array}$ & $\begin{array}{c}\text { Type I } \\
(n=76)\end{array}$ & $\begin{array}{l}\text { Type II } \\
(n=18)\end{array}$ & $\mathbf{p}$ \\
\hline Overall survival in months & 31.61 & 79.7 & 41.3 & $<0.001$ \\
\hline Disease free survival (DFS) in months & 29.47 & 87.2 & 24.7 & $<0.001$ \\
\hline Progression free survival (PFS), in months & 28.56 & 87.0 & 19.6 & $<0.001$ \\
\hline Survival rate (\%) & 83.9 & 92.1 & 55.5 & $<0.001$ \\
\hline
\end{tabular}


HIF-1 $\alpha$ expression in type I and II endometrial adenocarcinoma and its correlation with clinicopathological characteristics were analyzed (Table 9). The positivity of HIF-1 $\alpha$ expression showed no significant correlation with parameters of tumor features including cervical, myometrial and lymphovascular invasion and adnexal metastasis. High expression of HIF-1 $\alpha$ was observed in 1 of 9 recurrent endometrial adenocarcinoma case. The overall survival rate of patients with high HIF-1 $\alpha$ expression $(n=28)$ was $78.6 \%$ and of patients with negative HIF-1 $\alpha$ expression $(n=66)$ was $86.2 \%$. The median survival of patients with positive HIF-1 $\alpha$ expression was 61.2 months compared to 74.6 months for those with negative HIF-1 $\alpha$ expression. Although both overall survival rate and survival time were shorter in cases with high HIF-1 $\alpha$ expression, this relationship was not statistically different $(p=0.222)$ (Figure 4$)$.

Disease free survival (DFS) and progression free survival (PFS) of patients with positive and negative HIF-1 $\alpha$ expression followed a trend similar to overall survival. Longer durations were observed in patients with negative HIF-1 $\alpha$ expression but this was not found to be significant.

Microvessels were evaluated by immunohistochemical studies using CD34 antibody and average MVD was found as $46.7 \pm 6.9$

Table 6. Expression of HIF-1 $\alpha$ in type I and II endometrial adenocarcinoma

\begin{tabular}{|c|c|c|}
\hline \multicolumn{2}{|c|}{ Histological type } & \multirow{2}{*}{$\begin{array}{c}\begin{array}{c}\text { HIF-1 } \alpha(+) \\
(\mathbf{n}=94, \%)\end{array} \\
24(31.6 \%)\end{array}$} \\
\hline Type I & Endometrioid type $(n=76)$ & \\
\hline Type II & Serous type $(n=9)$ & $3(33.3 \%)$ \\
\hline & Clear-cell $(n=9)$ & $1(11.1 \%)$ \\
\hline \multicolumn{2}{|l|}{ Total } & 28 \\
\hline
\end{tabular}

Table 7. HIF-1 $\alpha$ expression according to the grades in type I endometrioid tumors

\begin{tabular}{|l|c|c|c|}
\hline & $\begin{array}{c}\text { Grade I } \\
(\mathbf{n}, \mathbf{\%})\end{array}$ & $\begin{array}{c}\text { Grade II } \\
(\mathbf{n}, \mathbf{\%})\end{array}$ & $\begin{array}{c}\text { Grade III } \\
(\mathbf{n}, \mathbf{\%})\end{array}$ \\
\hline $\mathrm{HIF}-1 \alpha(+)$ & $7 / 36(19.4 \%)$ & $14 / 30(46.7 \%)$ & $3 / 10(30 \%)$ \\
\hline
\end{tabular}

(Figure 5,6). A statistically significant difference was also noted in MVD between histological types $(\mathrm{p}<0.001)$. Average MVD was $45.24 \pm 6.61$ in type I tumors, whereas this was $52.98 \pm 4.55$ in type II tumors. Between grades, another significant difference was reported in MVD. Spearman's correlation test showed a significant positive correlation between MVD and grade $(p=0.009, r=0.268)$ (Figure 7). However, no correlation was seen between tumor stage, survival rates and MVD.

On analyzing the expression of immunohistochemical markers with each other, we found a significant correlation of HIF-1 $\alpha$ with MVD. High HIF-1 $\alpha$ expression showed higher MVD (Table 10), $(\mathrm{p}<0.001)$.

\section{Discussion}

Angiogenesis is vital in the development and progression of cancer. Malignant cells continuously proliferate and consume oxygen rapidly, resulting in a hypoxic microenvironment. This critical pathway is believed to be the primary regulator of angiogenesis. Recent studies showed regions of significant hypoxia

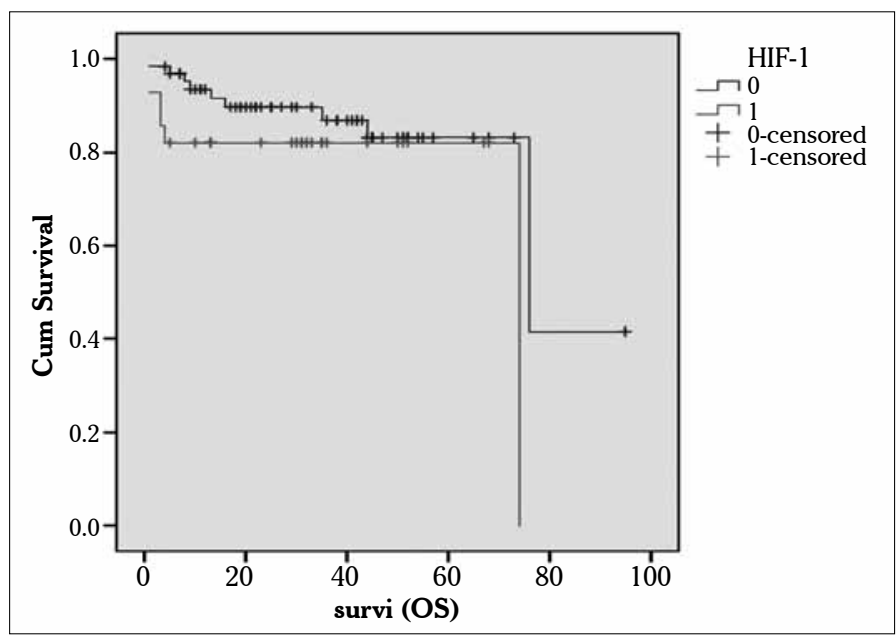

Figure 4. Overall survival of patients with HIF-1 $\alpha$ expression Cum Survival: Overall survival, Survi (OS): Survival in months 1: HIF-1 $\alpha$ positive 0: HIF-1 $\alpha$ negative, Kaplan-Meier method)

Table 8. HIF-1 $\alpha$ expression according to the stages

\begin{tabular}{|l|c|c|c|c|c|}
\hline & $\begin{array}{c}\text { Stage I } \\
(\mathbf{n}, \mathbf{\%})\end{array}$ & $\begin{array}{c}\text { Stage II } \\
(\mathbf{n}, \mathbf{\%})\end{array}$ & $\begin{array}{c}\text { Stage III } \\
(\mathbf{n}, \mathbf{\%})\end{array}$ & $\begin{array}{c}\text { Stage IV } \\
(\mathbf{n}, \mathbf{\%})\end{array}$ & Total \\
\hline HIF-1 $\alpha(+)$ & $15 / 53(28.3 \%)$ & $4 / 11(36.4 \%)$ & $7 / 27(25.9 \%)$ & $2 / 3(66.7 \%)$ & 28 \\
\hline HIF-1 $\alpha(-)$ & $38 / 53(57.6 \%)$ & $7 / 11(63.6 \%)$ & $20 / 27(74.1 \%)$ & $1 / 3(33.3 \%)$ & 66 \\
\hline
\end{tabular}

Table 9. HIF-1 $\alpha$ expression according to the clinicopathological features

\begin{tabular}{|l|c|c|c|}
\hline & $\begin{array}{c}\text { HIF-1 } \alpha(+) \\
(\mathbf{n})\end{array}$ & $\begin{array}{c}\text { HIF-1 } \alpha(-) \\
(\mathbf{n})\end{array}$ & $\mathbf{p}$ \\
\hline Recurrence $(\mathrm{n}=9)$ & 1 & 8 & 0.555 \\
\hline Cervical invasion $(+)(\mathrm{n}=31)$ & 10 & 21 & 0.811 \\
\hline Myometrial invasion (+) $(\mathrm{n}=84)$ & 25 & 59 & 0.622 \\
\hline Adnexal involvement $(+)(\mathrm{n}=20)$ & 5 & 15 & 0.784 \\
\hline Lymphovascular invasion $(+)(\mathrm{n}=34)$ & 10 & 24 & 0.573 \\
\hline
\end{tabular}




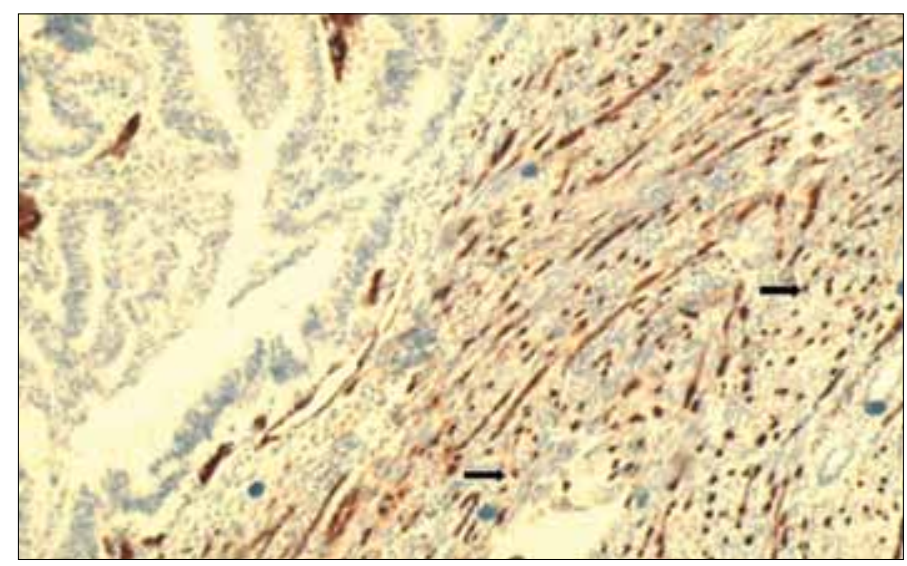

Figure 5. CD34 positivity in endometrioid type adenocarcinoma (CD34, X200)

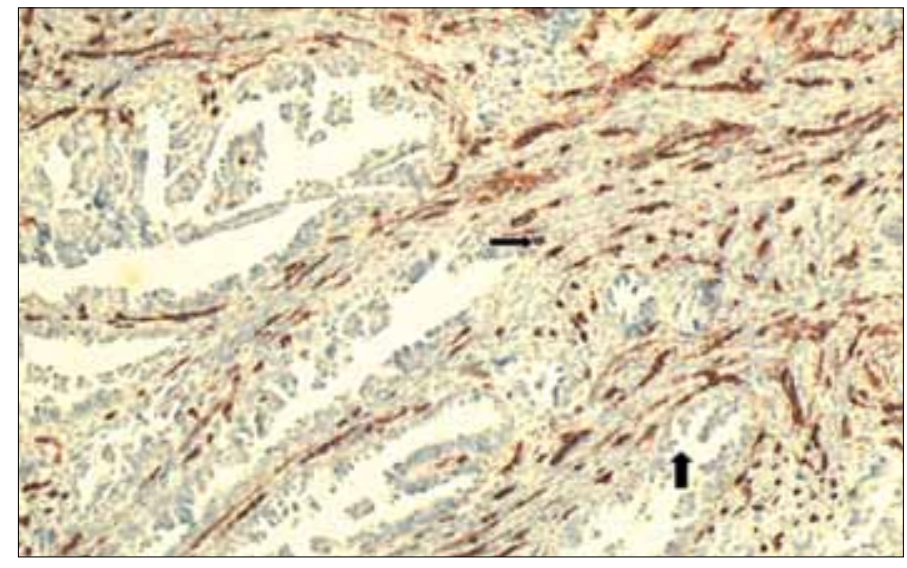

Figure 6. CD34 positivity in serous type adenocarcinoma (CD34, X200)



Figure 7. CD34 was correlated with grade

(Spearman's correlation test)

in many tumors (12). HIF-1, a heterodimeric transcription factor, is the key survival gene for cells in a hypoxic environment. HIF-1 is a nuclear factor that is induced in hypoxic cells, composed of HIF- $1 \alpha$ and HIF-1 $\beta$ subunits. HIF-1 activates the expression
Table 10. HIF-1 $\alpha$ expression and MVD

\begin{tabular}{|l|c|}
\hline & CD34 (MVD) \\
\hline HIF-1 $\alpha(+)$ & $48.27 \pm 8.04$ \\
\hline HIF-1 $\alpha(-)$ & $42.61 \pm 5.50$ \\
\hline $\mathrm{p}$ & $<0.001$ \\
\hline
\end{tabular}

of over 40 genes at the transcriptional level. In this study, we investigated the immunohistochemical expressions of HIF-1 $\alpha$ and CD34 in type I and type II endometrial adenocarcinomas. HIF- $1 \alpha$ is over-expressed in various tumors such as cervical cancer, gastrointestinal stromal tumors, lung cancers, bladder tumors (13-15). It has been shown that HIF-1 $\alpha$ is released by two mechanisms in tumor cells. In solid tumors like glioblastoma multiforme, chronic hypoxia is the leading cause of HIF-1 $\alpha$ expression. Another way is by a genetic pathway. Tumors with high vascularization such as colon cancers, hemangioblastoma and renal cell carcinomas exhibit HIF-1 $\alpha$ expression in this manner. In endometirum cancers, chronic hypoxia-associated HIF-1 $\alpha$ expression has been reported in the literarute $(16,17)$. HIF-1 $\alpha$ overexpression has been described in endometrial cancers $(18,19)$. Sivridis et al. (18) found overexpression of HIF-1 $\alpha$ in $49 \%$ of women with Stage I endometrioid adenocarcinomas. However, in this study, other histological types of endometrial carcinomas and different stages have not been included. Pansare et al. (19) also investigated HIF-1 $\alpha$ expression in endometrial cancers and only endometrioid and serous cell cancers were defined in their study. However, unlike the previous ones, our study evaluated both type I and type II tumors which included clear cell adenocarcinomas of the endometrium additionally and all stages of endometrium cancer cases.

The findings of our study showed that HIF-1 $\alpha$ expression was observed in $31.6 \%$ of endometrioid, $33.3 \%$ of serous cell and $11.1 \%$ of clear cell tumors. There was no significant difference between these three histological types. To the best of our knowledge, this is the first study comparing the expression of HIF- $1 \alpha$ in three types of endometrial adenocarcinomas. Our result did not support those of previous studies according to the histological types. Pansare et al. showed that HIF-1 $\alpha$ expression reported in $80 \%$ of type II and $26 \%$ of type I tumors. Lee et al. also studied HIF-1 $\alpha$ expression in ovarian cancers and they found that, in clear cell tumors HIF-1 $\alpha w a$ expressed more than in endometrioid and serous cell cancers (20). On the other hand, Osada et al. found that there was no difference in HIF-1 $\alpha$ expression of various histological types of ovarian cancers (21). Stage is known as the most important prognostic factor in endometrium cancer. In advanced stages, survival of patients declines. In the present study, the positivity of HIF-1 $\alpha$ expression was seen in $15(53.5 \%)$ of stage I, 4 (14.2\%) of stage II, 7 (25\%) of stage III and $2(7.1 \%)$ of stage IV cases. Our study showed no significant difference in HIF-1 $\alpha$ expression between various stages of endometrial adenocarcinoma. In the literature, the association of stage and HIF-1 $\alpha$ expression was investigated (19). In type I endometrial cancer, high expression of HIF-1 $\alpha$ showed a significant correlation with advanced stages. However this correlation was not observed in type II tumors. Likewise, Ozbudak et al. showed increased rates of HIF-1 $\alpha$ 
high expression in advanced stages of endometrioid adenocarcinoma (22).

Increased HIF-1 $\alpha$ expression is associated with aggressive tumor behaviour and ability to metastasize. As a result of this, cervical, myometrial and lymphovascular invasion and adnexial involvement were seen more frequently. In one study, myometrial and adnexial involvement were revealed in a group of patients with high HIF-1 $\alpha$ expression (19). However, Sivridis et al. showed that there was no relation between myometrial and lymphovascular invasion and HIF- $1 \alpha$ expression (18). In this study, we also found no correlation between tissue invasion and HIF-1 $\alpha$ expression.

In the present study, the HIF-1 $\alpha$ staining pattern was shown to be statistically different in various grades of the tumors. High expression of HIF-1 $\alpha$ was significantly different in advanced grades. After exluding all type II grade III tumors from the analysis, we still found a similar correlation with grade and HIF-1 $\alpha$ expression $(p=0.008)$. Contradictory results have been described in the comparison of grade with the HIF-1 $\alpha$ overexpression in endometrial carcinoma. Increased HIF-1 $\alpha$ expression has been reported in low grade tumors in endometrial cancers (18). In ovarian tumors, high HIF-1 $\alpha$ expression was correlated with grade of the tumors. However, in pancreatic ductal adenocarcinoma, no association was observed between grade and HIF-1 $\alpha$ expression $(20,23)$.

Although endometrium cancer is the most common female genital tract cancer, the majority are diagnosed at an early stage and they are associated with a favorable prognosis. Recurrence develops in 10-15\% of patients and is limited to the pelvic cavity in half of the cases. During follow-up, 9 cases developed recurrence and in 5 of them, a vertebra was the recurrence site. Recurrence is usually reported in two years after the initial surgery. Likewise, the average recurrence time in our study was 21.5 months. In this study, MVD was measured by immunohistochemistry using CD34. In predicting prognosis by calculating microvessels, CD34 was shown to have better results than other antibodies (24). Our findings revealed that MVD was significantly higher in type II tumors than type I tumors $(52.98 \pm 4.55$ vs $45.24 \pm 6.61)$ $(\mathrm{p}<0.001)$. Since type II tumors are more aggressive and are related to high grades, these results with MVD are consistent with the literature. Our results further demonstrated that a significant correlation has been reported in advanced grades with MVD. We found that values of MVD increased gradually through early to advanced grades of endometrial adenocarcinoma $(p=0.009, r=0.268)$. Our findings also showed that the relationship between the HIF-1 $\alpha$ expression and MVD was statistically significant $(p<0.001)$. This result confirmed the relationship between hypoxia and angiogenesis.

Studies evaluating HIF-1 $\alpha$ in cancers other than endometrial cancer have revealed that patients with tumors that express high levels of HIF-1 $\alpha$ have a poor outcome (25). Birner et al. (26) demonstrated shorter survival rates of patients with high HIF- $1 \alpha$ expression in early stage invasive cervical cancers. However, contradictory results have been described as to the prognostic value of HIF-1 $\alpha$ overexpression in endometrial carcinoma. Pansare et al. (19) reported that HIF-1 $\alpha$ expression did not show a correlation with survival in endometrial cancer. On the other hand, Sivridis et al. (18) showed that overexpression of HIF- $1 \alpha$ is associated with a poor prognosis. In our investigation, we found no relationship between survival rates and HIF$1 \alpha$ expression. As a result, correlation of HIF-1 $\alpha$ with survival and prognosis is still under discussion. On the other hand, our data is limited in terms of evaluating survival rates. Since our median follow-up time was $31 \pm 10.6$ months, the range (1-95 months) of follow-up was wide and inconclusive.

HIF- $1 \alpha$ staining is detected in both the nucleus and cytoplasm of the cell. However HIF-1 $\alpha$ is only activated in the nucleus. In some studies, both nuclear and cytoplasmic staining was scored. In our study, we took into account nuclear staining only. Nonetheless, immunohistochemical studies are difficult to evaluate and conflicting data in the literature about HIF-1 $\alpha$ staining is still under investigation.

In conclusion, high expression of HIF-1 $\alpha$ is associated with tumoral angiogenesis in endometrial adenocarcinomas. Further studies targeting HIF-1 $\alpha$ for disrupting mechanisms essential for tumor growth in endometrial cancer will be significant a investigations in the future.

\section{Conflict of interest}

No conflict of interest was declared by the authors.

\section{References}

1. Kurman RJ. Blaustein's Pathology of the Female Genital Tract, 5th Ed. Springer: New York, 2002: pp. 501-60.

2. Hecht LJ, Mutter GL. Molecular and pathologic aspects of endometrial carcinogenesis. J Clin Oncol 2006; 24: 4783-91. [CrossRef]

3. Harris AL. Hypoxia - a key regulatory factor in tumour growth. Nat Rev Cancer 2002; 2: 38-47. [CrossRef]

4. Wang GL, Jiang BH, Rue EA, Semenza, GL. Hypoxia-inducible factor 1 is a basic-helix-loophelix- PAS heterodimer regulated by cellular O2 tension. Proc Natl Acad Sci USA 1995; 92: 5510-14. [CrossRef]

5. Semenza GL. Hypoxia-inducible factor 1: oxygen homeostasis and disease pathophysiology. Trends Mol Med 2001; 7: 345-50. [CrossRef]

6. Zhong H, De Marzo A, Laughner E, Lim M, Hilton DA, Zagzag D, et al. Overexpression of hypoxia-inducible factor 1a in common human cancers and their metastases. Cancer Res 1999; 59: 5830-35.

7. Horrée N, van Diest PJ, van der Groep P, Sie-Go DM, Heintz AP. Hypoxia and angiogenesis in endometrioid endometrial carcinogenesis. Cell Oncol 2007; 29: 219-27.

8. Tavassoli FA, Devilee P. Tumours of the uterine corpus. In: Tavassoli FA, Devilee P. World Health Organization Classification of Tumours of the Breast and Female Genital Organs. Germany: IARC Press 2003. pp. 217-57.

9. Kim HS, Song YS. International Federation of Gynecology and Obstetrics (FIGO) staging system revised: what should be considered critically for gynecologic cancer? J Gynecol Oncol 2009; 20: 135-6. [CrossRef]

10. Yoshimura H, Dhar DK, Kohno H, Kubota H, Fujii T, Ueda S, et al. Prognostic impact of hypoxia-inducible factors 1alpha and 2alpha in colorectal cancer patients: correlation with tumor angiogenesis and cyclooxygenase-2 expression. Clin Cancer Res 2004; 10 : 8554-60. [CrossRef]

11. Weidner N, Semple JP, Welch WR, Folkman J. Tumor angiogenesis and metastasis-correlation in invasive breast carcinoma. $\mathrm{N}$ Engl J Med 1991; 324: 1-8. [CrossRef] 
12. Airley R, Loncaster J, Davidson S, Bromley M, Roberts S, PattersonA, et al. Glucose transporter glut-1 expression correlates with tumor hypoxia and predicts metastasis-free survival in advanced carcinoma of the cervix. Clin Cancer Res 2001; 7 : 928-34.

13. No JH, Jo H, Kim SH, Park IA, Kang D, Han SS, et al. Expression of vascular endothelial growth factor and hypoxia inducible factor$1 \alpha$ in cervical neoplasia. Ann N Y Acad Sci 2009; 1171: 105-10. [CrossRef]

14. Hung JJ, Yang MH, Hsu HS, Hsu WH, Liu JS, Wu KJ. Prognostic significance of hypoxia-inducible factor-1 a, TWIST1 and Snail expression in resectable non-small cell lung cancer. Thorax 2009; 64: 1082-9. [CrossRef]

15. Deniz H, Karakök M, Yagcı F, Güldür ME. Evaluation of relationship between HIF- $1 \alpha$ immunoreactivity and stage, grade, angiogenic profile and proliferative index in bladder urothelial carcinomas. Int Urol Nephrol 2010; 42: 103-7. [CrossRef]

16. Dewhirst MW. Relationships between Cycling Hypoxia, HIF-1, Angiogenesis and Oxidative Stress. Radiat Res 2009; 172: 653-65. [CrossRef]

17. Seeber LM, Zweemer RP, Verheijen RHM, van Deist PJ. Hypoxiainducible factor- 1 as a therapeutic target in endometrial cancer management. Obstet Gynecol Int 2010; 2010: 580971.

18. Sivridis E, Giatromanolaki A, Gatter K, Haris AL, Koukourakis MI. Association of hypoxia-inducible factors 1a and $2 \mathrm{a}$ with activated angiogenic pathways and prognosis in patients with endometrial carcinoma. Cancer 2002; 95: 1055-63. [CrossRef]

19. Pansare V, Munkarah AR, Schimp V, Haitham Arabi M, Saed GM, et al. Increased expression of hypoxia-inducible factor 1 alpha in type I and type II endometrial carcinomas. Mod Pathol 2007; 20: 35-43. [CrossRef]
20. Lee S, Garner El, Welch WR, Berkowitz RS, Mok SC. Overexpression of hypoxia- inducible factor 1 alpha in ovarian clear cell carcinoma. Gynecol Oncol 2007; 106: 311-7. [CrossRef]

21. Osada R, Horiuchi A, Kikuchi N, Yoshida J, Hayashi A, Ota M, et al. Expression of hypoxia-inducible factor lalpha, hypoxia-inducible factor 2alpha, and von Hippel-Lindau protein in epithelial ovarian neoplasms and allelic loss of von Hippel-Lindau gene: nuclear expression of hypoxia-inducible factor lalpha is an independent prognostic factor in ovarian carcinoma. Hum Pathol 2007; 38: 1310-20. [CrossRef]

22. Ozbudak IH, Karaveli S, Simsek T, Erdogan G, Pestereli E. Neoangiogenesis and expression of hypoxia-inducible factor $1 \alpha$, vascular endothelial growth factor, and glucose transporter-1 in endometrioid type endometrium adenocarcinomas. Gynecol Oncol 2008; 108: 603-8. [CrossRef]

23. Zhang JJ, Wu HS, Wang L, Tian Y, Zhang JH, Wu HL. Expression and significance of TLR4 and HIF-1 $\alpha$ in pancreatic ductal adenocarcinoma. World J Gastroenterol 2010; 16: 2881-8. [CrossRef]

24. Toge $\mathrm{H}$, Inagaki T, Kojimoto $\mathrm{Y}$, Shinka T, Hara I. Angiogenesis in renal cell carcinoma: the role of tumor-associated macrophages. Int J Urol 2009; 16: 801-7. [CrossRef]

25. Nakamura J, Kitajima Y, Kai K, Hashiguchi K, Hiraki M, Noshiro H et al. HIF-la is an unfavorable determinant of relapse in gastric cancer patients who underwent curative surgery followed by adjuvant 5-FU chemotherapy. Int J Cancer 2010; 127: 1158-71. [CrossRef]

26. Birner P, Schindl M, Obermair A, Plank C, Breitenecker G, Oberhuber G. Overexpression of hypoxia-inducible factor 1alpha is a marker for an unfavorable prognosis in early-stage invasive cervical cancer. Cancer Res 2000; 60: 4693-6. 